\title{
Examination of Reading Strategies Metacognitive Awareness Levels of French Foreign Language Students in Terms of Various Variables
}

\author{
Zühre Yılmaz Güngör ${ }^{1, *}$ \\ ${ }^{1}$ Faculty of Education, French Language Teaching Department, Anadolu University, Eskişehir, Turkey \\ *Correspondence: Faculty of Education, French Language Teaching Department, Anadolu University, Eskişehir, \\ Turkey. E-mail: zuhreyilmaz@gmail.com
}

Received: August 19, 2021

Accepted: September 25, $2021 \quad$ Online Published: October 12, 2021

doi:10.5430/wje.v11n5p31

URL: https://doi.org/10.5430/wje.v11n5p31

\begin{abstract}
The act of reading is a complex process in which learners rush their cognitive and metacognitive skills to fonction. The effective use of metacognitive skills is regarded as an important feature becoming prominent in successful reading. In order to exercise reading strategies effectively, students are required to have developed metacognitive awareness. In this study, the level of metacognitive awareness of reading strategies and whether metacognitive awareness varies according to variables such as gender and reading course success have been examined in the $1^{\text {st }}$ grade students studying at Anadolu University Faculty of Education Program of French Language Teaching Program. 32 students voluntarily participated in the study, 19 of whom were Females and 13 of whom were Males. The data of the study have been collected with the Turkish version of the 30-item 5-point Likert-type Metacognitive Awareness of Reading Strategies Inventory (MARSI) developed by Mokhtari \& Reichard (2002) and adapted into Turkish by Öztürk (2012). According to the findings, students' reading strategies were revealed to have high levels of metacognitive awareness. However, it has been further observed that the level of metacognitive awareness of students' reading course success grades and reading strategies did not make a significant difference in terms of gender. Similarly, it has been observed that there was no significant difference between the students' reading strategies and metacognitive awareness levels and their success grades in the reading course.
\end{abstract}

Keywords: metacognitive awareness, metacognition, reading in a foreign language, reading strategies, French

\section{Introduction}

In foreign language teaching, reading skill, one of the four skills aimed to be acquired by students, is regarded substantial in terms of contributing to the language development of students. Achieving success in learning a foreign language not only depends on comprehending the rules of grammar, having a sufficient vocabulary, understanding what you hear in a foreign language, but also being able to understand what you read.

As in the mother tongue, the act of reading in the target language is considered as a complex process and may vary depending on the context, the reader's goals, attitude, and motivation. In the reading-comprehension process, the individual is required to be capable of controlling his own learning and benefiting from certain strategies in order to be successful. "According to Schmitt (1986), since the early of the $20^{\text {th }}$ century, researchers have argued that the reading skill, known as metacognitive skills, includes activities of planning (choosing appropriate strategies and effectively allocating resources to complete a task), checking (observing task comprehension and identifying targets for optimal performance) and evaluation (appraising the regulatory process and the efficiency with which a task is completed)" (Bedir \& Dursun, 2020; Teng, 2019). Therefore, nowadays certain metacognitive actions such as knowing how the individual is required to work and think during the process of reading, planning the reading, checking whether or not understanding are of utmost importance.

\subsection{Metacognition}

The word "meta", which is used to express the concept of metacognition, refers to the conical columns used in Roman circuses to mark the turning points of the races. This is similar to the concept of meta-cognition can be seen as a turning point in our understanding of the mind. The prefix meta has come to refer to something that transcends 
the subject it is related to (Ficher, 1998).

Research (Aktürk \& Şahin, 2011, cited by Gül, 2020) on metacognition has its origins in cognitive psychology according to Peters (2007), cognitive developmental psychology according to Hart (1965) and Steinbach (2008), and social developmental psychology according to Piaget (1950) and Tsai (2001). The concept of metacognition, first used by Flavell in the 1970s, was defined as the cognitive monitoring process occurring as a result of the interaction between metacognitive knowledge, metacognitive experiences, goals and actions (Özsoy, 2008, cited by Başaran, 2013). In other words, according to the definition of Flavell (1976), metacognition is referring to that uniquely human capacity of people to be self-reflexive, not just to think and know but to think about their own thinking and knowing (Ficher, 1998). Metacognition has become a more popular concept in the subsequent years and has been used in many fields as well as in education (Dimmitt \& McCormick, 2012). According to this, metacognition is considered as a key competency for successful learning in a wide range of domains, including education (Stephanou \& Mpiontini, 2017).

Many different definitions of metacognition are available in the literature. Metacognition can be defined simply as thinking about thinking (Anderson, 2002). Wenden (1987) defines metacognitive knowledge as "the knowledge one has about one's own learning" (Haukas, 2018). According to Pressley and Gaskins (2006), metacognition is referred to as "a concept providing information about when and where reading strategies are required be applied to improve reading comprehension". According to Schramm (2006, cited by Erdoğan \& Yurdabakan, 2018), "metacognition in reading involves not only strategy awareness and perceived strategy use, but also the actual regulation and control of the reading process". Likewise, Vianty (2007) asserts a similar definition and defines metacognition as a process that includes thinking about the learning process, planning and understanding the learning process, following the mental product in the process and evaluating the learning product. Mokhtari and Reichard (2002) define metacognition as a cognitive skill applied to enhance the emotional qualities of thinking and cognitive knowledge.

Two different dimensions of metacognition are mentioned in the literature (Baker and Brown, 1984, cited by Pinninti, 2016; Pereira and Deane, 1997, cited by Başaran, 2013). The first dimension is about cognitive processes, which is the thinking. Cognitive strategies or the information obtained on which cognitive strategy to apply in which situation can be given as an example of this dimension of metacognition. The second dimension is about applying metacognitive strategies. Self-regulation or controlling thought are among the skills related to this dimension. As it can be acknowledged in here, the area covered by metacognition is as wide as possible.

Effective exercise of metacognitive skills is considered as an important feature in successful reading. In many research, it has been noted that individuals who are successful in reading are also more effective at exercising their metacognitive skills comparing to readers having reading skills to a lesser extent (Sucu, 2009).

In consideration of the characteristics of people with advanced metacognitive skills, it has been observed that the following skills have been developed accordingly. (Azizoğlu \& Okur, 2020):

- being aware of their abilities and skills,

- choosing their learning methods,

- applying learning strategies effectively,

- being successful in the learning process,

- being able to evaluate their own learning processes,

- being able to use their previous knowledge effectively,

- being able to find suitable solutions to problems,

- being able to prepare an action plan for the problems,

- being able to examine any subject with questions such as what/why/how/when,

- having advanced questioning skills.

Based on these entire definitions, metacognition is a process of high-level thinking, and according to some researchers it is also considered as the 'seventh sense' and one of the mental characteristics exercised by successful learners (Rahimi \& Katal, 2012).

\subsection{Reading Strategies and Metacognitive Awareness}

"Reading", an action frequently practiced in daily life, has an important place in foreign language education as it enables the individual to acquire information by being aware of the outside world. For this reason, providing students 
with reading skills and improving their reading comprehension levels in language teaching are among the primary objectives of teachers. The first step of ensuring that students are good readers is to ensure that they are aware of their reading strategies and learn to exercise them accurately when necessary. Therefore, the primary objective of reading is required to be comprehension, and this can only be achieved through strategic reading. Hence, it is clear that no act of reading that does not result in comprehension can accomplish its objectives. Briefly, the good reader is a strategic reader, and he knows how to approach the text (Şahan, 2012).

As psychologist P. Riley (1985, cited by Rui, 2000) has emphasized, the term strategy has become an important word in the social sciences in the 1980s, especially because it provides an epistemological bridge between intention and action. According to Williams (1989, cited by Cornaire, 1999), "strategy" in foreign language teaching is a conscious step taken to solve a problem or achieve a goal. Reading strategies are the names given to the techniques helping for the solution of the problems encountered during reading, increase the efficiency of reading, and contribute to the development of the individual's comprehension level (Akkaya, 2011). For this reason, students need to learn how to apply reading strategies in order to reach their reading objectives (Ay, 2008).

If reading strategies are required to be defined, it can be said that certain mental tactics are available for the individuals to exercise during reading in order to make it easier to extrapolate the texts. In other words, reading strategies demonstrate how readers perceive reading, how they read, how they perceive and what they do if they do not understand. (Block, 1986, cited by Çetinkaya, 2004).

Many researchers have grouped and named their reading strategies in various forms. According to Reid (2007), reading strategies consist of scanning (scanning), superficial reading (skimming) and detailed reading strategies. In his study, Zhang (1993) divided reading strategies in 4 groups: cognitive strategies, compensation strategies, memory strategies, and evaluation strategies. Auerbach \& Paxton (1997) addressed these strategies to be grouped in 3 categories: pre-reading strategies, during reading strategies, and post-reading strategies. In the scale developed by Mokhtari \& Reichard (2002) and used in many studies, reading strategies are again discussed in three different groups: Global Reading Strategies, Problem Solving Strategies and Support Reading Strategies.

Despite the various groupings we have mentioned so far, reading strategies are often divided into three as pre-reading, during reading and post-reading strategies in the literature (Susar Kırmızı, 2009, cited by Aktaş \& Ertem, 2016):

1. Pre-reading strategies: refers to reviewing/examining the text, identifying key words, determining reading purposes, using prior knowledge, forming questions and making guesses/creating hypotheses.

2. Strategies during reading: refers to identifying words, establishing relationships, visualizing, seeking answers to questions and creating new questions, focusing on purpose, checking guesses/hypotheses, underlining, taking notes, identifying complex points, fluent reading.

3. Post-reading strategies: refers to summarizing, answering questions, synthesizing, explaining and evaluating text with visual elements.

The strategies for each individual to choose for themselves differ according to their own reading goals and stages, because the problems experienced by the readers in the reading process are different from each other (Gül, 2020).

In general, the act of reading is a complex process requiring the use of cognitive and metacognitive strategies, and students apply strategies while controlling this process. Students can apply these entire strategies accurately and appropriately, only if their metacognitive awareness and skills are developed (Carrell, 1989). Individuals with advanced metacognitive awareness are aware of what they know and do not know, their own cognitive processes, can evaluate and plan their own learning, control their mental processes, take responsibility for learning, reading strategies and apply them effectively (Bağçeci et al., 2011, cited by Azizoğlu \& Okur, 2020). According to those who adopt the cognitive approach, certain processes taking place in the learner's mind affect learning (Bacanl1, 2004, cited by Temizkan, 2008). Therefore, thinking about cognitive processes or metacognition in reading reveals the focus of reading comprehension research, Grigorenko \& Sternberg, 2008). Metacognitive knowledge or metacognitive awareness refers to learner's knowledge about their personal strengths and weaknesses, pertains to a specific task, and may vary between tasks, strategies, goals, and other relevant to achievement of a pursuit goal information (Efklides, 2008; Perry, 2013; Tanner, 2012, cited by Stephanou \& Mpiontini, 2020). So, in short, metacognitive awareness involves the awareness of whether or not comprehension is occurring, and the conscious application of one or more strategies to correct comprehension (Wang, 2009).

Students with a high level of metacognitive awareness know what to do if they encounter a problem while reading, and they apply certain strategies to understand what they read. In the foreign language learning process, the application of metacognitive strategies motivates students to think, provides a deeper learning and increases the 
performance of students who face challenges in language learning. If we review the studies conducted with successful and weak readers, it is observed that successful readers "apply their full attention to reading, anticipate the text before reading, exercise reading strategies, analyze the content, identify keywords, organize new and old information, and know what they have learned by checking their levels of comprehension" (Bråten et al., 2010; Palincsar \& Brown, 1984, cited by Kuruyer \& Özsoy, 2016).

When we review the literature, it is observed that successful readers are aware of their reading strategies the way they exercise them consciously, as well as being conscious of metacognition.

Examining the variables affecting the reading strategies metacognitive awareness generally focuses on learners of English as a foreign language. Considering that the studies conducted with those who learn French as a foreign language are limited, it is considered that this study shall contribute to the literature on the subject. The study aims to identify the reading strategies metacognitive awareness levels of $1^{\text {st }}$ grade students studying in the Anadolu University Faculty of Education Program of French Language Teaching and examine these in terms of various variables. Within the framework of this purpose, answers to the following questions were sought:

1. What is the level of metacognitive awareness of reading strategies of French foreign language students?

2. Is there a significant gender difference between students' reading success grades and reading strategies metacognitive awareness levels?

3. Is there a significant difference between students' reading strategies metacognitive awareness levels and their success grades in the reading course?

\section{Method}

\subsection{Model of the Research}

The reading metacognitive awareness levels of the $1^{\text {st }}$ grade students participating in the research were examined in accordance with two variables: gender and reading course success grade. Accordingly, the research is patterned on the relational screening model. Relational screening models are research models that aim to identify the existence and/or degree of co-variation between two or more variables, and there are many application areas. (Karasar, 1995: $81)$.

\subsection{Study Group}

The participants of the study are the $1^{\text {st }}$ grade students studying in the Program of French Language Teaching of the Faculty of Education of Anadolu University. 32 students have voluntarily participated in the study, 19 of whom were Females and 13 of whom were Males. It is regarded that the foreign language levels of the students are at the level of A2-B1 in accordance with the CEFR (The Common European Framework of Reference for Languages). Descriptive information about the participants is presented in Table 1.

Table 1. Distribution of Students by Gender

\begin{tabular}{lcc}
\hline Gender & $f$ & $\%$ \\
\hline Female & 19 & 59.4 \\
Male & 13 & 40.6 \\
Total & 32 & 100.0 \\
\hline
\end{tabular}

As seen in Table $1,59.4 \%$ of the participants were female ( $\mathrm{f}=19)$, while $40.6 \%$ were male $(f=13)$.

\subsection{Data Collection Tools}

The Turkish version of the Metacognitive Awareness of Reading Strategies Inventory (MARSI) consisting of 30 items developed by Mokhtari and Reichard (2002) has been applied to determine the participants' reading strategies and metacognitive awareness levels. In the scale, it is aimed to determine metacognitive awareness towards Global Reading Strategies, Problem Solving Strategies and Support Reading Strategies. According to the scoring rubric suggested by Mokhtari \& Reichard (2002), 3.5 and above $=$ High, between 2.5-3.4 = Medium, and 2.4 or below $=$ Low level of reading strategy use.

The general reliability of the Reading Strategies Metacognitive Awareness scale was found to be highly reliable as $\alpha=0.914$. When the reliability of the sub-dimensions of the scale was examined, the reliability of the Global Reading 
Strategies sub-dimension was calculated as $\alpha=0.896$, the reliability of the Problem-Solving Strategies sub-dimension $\alpha=0.801$, and the reliability of the Support Reading Strategies sub-dimension as $\alpha=0.874$.

\subsection{Analysis of Data}

The data has been analyzed with SPSS V23. The Shapiro-Wilk test of compliance with the normal distribution in the data obtained and two independent sample t-tests have been used to compare the normal distribution data by gender. In the study of the relationship between normal distributed reading course success grade and scale scores, the Pearson correlation coefficient was applied. Analysis results are presented as mean \pm standard deviation (SD) and median (minimum - maximum) for quantitative data. Significance level was applied as $p<0.050$.

\section{Findings and Discussion}

The $1^{\text {st }}$ question of the study was "What is the level of metacognitive awareness of reading strategies of French foreign language students?". The related findings are given in Table 2.

Table 2. Descriptive Statistics of Variables

\begin{tabular}{lcc}
\hline & $\begin{array}{c}\text { Frequency }(n) / \text { Mean } \pm \\
\text { deviation }\end{array}$ & $\begin{array}{c}\text { Percent }(\%) / \text { Mean }(\min . \\
\text { - max.) }\end{array}$ \\
\hline Gender & 19 & 59,4 \\
Female & 13 & 40,6 \\
Male & $68,03 \pm 11,67$ & $66,80(51,60-93,00)$ \\
Reading Class Success Score & $3,75 \pm 0,55$ & $3,85(2,50-4,80)$ \\
Global Reading Strategies & $3,87 \pm 0,49$ & $3,95(3,00-4,60)$ \\
Problem Solving Strategies & $3,51 \pm 0,49$ & $3,60(2,70-4,90)$ \\
Support Reading Strategies & $3,71 \pm 0,38$ & $3,70(3,00-4,30)$ \\
Reading Strategies Metacognitive & & \\
Awareness Scale Overall Score & & \\
\hline
\end{tabular}

Table 2 indicates the students' Reading Class Means, Global Reading Strategies - Problem Solving Strategies Support Reading Strategies. However, Table 2 also includes the general scores of Reading Strategies Metacognitive Awareness levels.

In the light of the data obtained accordingly, it has been determined that the students' reading course success point average is 68.03. This mean is listed as an intermediate score based on the transcript of the Anadolu University (Table 3).

Table 3. Grade Sheet of the Anadolu University Absolute System and Credit System

\begin{tabular}{ccc}
\hline \multirow{2}{*}{$\begin{array}{c}\text { Absolute System (out of } \\
\text { 100) }\end{array}$} & \multicolumn{2}{c}{ Credit System (out of 4.00) } \\
\cline { 2 - 3 } & $\begin{array}{c}\text { Letter } \\
\text { equivalent }\end{array}$ & $\begin{array}{c}\text { Grade } \\
\text { Value }\end{array}$ \\
\hline $84-100$ & AA & 4.00 \\
$77-83$ & AB & 3.70 \\
$71-76$ & BA & 3.30 \\
$66-70$ & BB & 3.00 \\
$61-65$ & BC & 2.70 \\
$56-60$ & CB & 2.30 \\
$50-55$ & CC & 2.00 \\
$46-49$ & CD & 1.70 \\
$40-45$ & DC & 1.30 \\
$33-39$ & DD & 1.00 \\
$0-32$ & FF & 0.00 \\
\hline
\end{tabular}


Considering the strategy scores, it has been determined that the mean of the students' Global Reading Strategies score was 3.75, the mean of the Problem-Solving Strategies score was 3.87, and the mean of the Strategies that Support Reading was 3.51. The overall mean score of the Reading Strategies Metacognitive Awareness Scale was determined as 3.71. Considering this situation, according to the scoring key suggested by Mokhtari \& Reichard (2002), it is revealed that students exercise the entire strategies at a high level ( 3.5 and above $=$ High).

The findings regarding the $2^{\text {nd }}$ question (Is there a significant gender difference between students' reading success grades and reading strategies metacognitive awareness levels?) of the research are presented in Table 4 and Table 5. It is not feasible to present the entire data for Females and Males in a single table because it would not fit in the page layout, and therefore, they are presented in two separate tables. Accordingly, the Test statistic and $p$, which are common calculations, are included in both tables.

Table 4. Comparison of Reading Course Success Score and Reading Strategies Metacognitive Awareness Scores by Gender

\begin{tabular}{lcccc}
\hline & \multicolumn{2}{c}{ Female } & Test Statistic & $\mathrm{p}$ \\
\cline { 2 - 5 } & $\begin{array}{c}\text { Mean } \pm \mathrm{s} . \\
\text { deviation }\end{array}$ & Mean $($ min. - max.) & Female+Male & Female+Male \\
\hline Reading Class Success Score & $65,09 \pm 11,83$ & $63,40(51,60-93,00)$ & $\mathrm{t}=-1,776$ & 0,086 \\
Global Reading Strategies & $3,72 \pm 0,60$ & $3,90(2,50-4,80)$ & $\mathrm{t}=-0,314$ & 0,756 \\
Problem Solving Strategies & $3,86 \pm 0,50$ & $3,90(3,00-4,60)$ & $\mathrm{t}=-0,148$ & 0,883 \\
Support Reading Strategies & $3,47 \pm 0,56$ & $3,40(2,70-4,90)$ & $\mathrm{t}=-0,561$ & 0,579 \\
Reading Strategies Metacognitive & $3,68 \pm 0,39$ & $3,70(3,00-4,30)$ & $\mathrm{t}=-0,388$ & 0,701 \\
Awareness Scale Overall Score & & & & \\
\hline
\end{tabular}

t: Independent two-sample t-test statistic

Table 5. Comparison of Reading Course Success Score and Reading Strategies Metacognitive Awareness Scores by Gender

\begin{tabular}{lcccc}
\hline & \multicolumn{2}{c}{ Male } & Test Statistic & $\mathrm{p}$ \\
\cline { 2 - 5 } & Mean \pm s. deviation & Mean (min. - max.) & Female+Male & Female+Male \\
\hline Reading Class Success Score & $72,31 \pm 10,40$ & $75,60(53,60-90,00)$ & $\mathrm{t}=-1,776$ & 0,086 \\
Global Reading Strategies & $3,78 \pm 0,51$ & $3,80(3,20-4,80)$ & $\mathrm{t}=-0,314$ & 0,756 \\
Problem Solving Strategies & $3,88 \pm 0,50$ & $4,10(3,10-4,60)$ & $\mathrm{t}=-0,148$ & 0,883 \\
Support Reading Strategies & $3,57 \pm 0,40$ & $3,60(2,90-4,10)$ & $\mathrm{t}=-0,561$ & 0,579 \\
Reading Strategies & $3,74 \pm 0,39$ & $3,60(3,10-4,30)$ & $\mathrm{t}=-0,388$ & 0,701 \\
Metacognitive Awareness Scale & & & & \\
Overall Score & & & & \\
\hline
\end{tabular}

t: Independent two-sample t-test statistic

When the findings in Table 4 and Table 5 are examined, it is seen that there is no statistically significant relationship between the students' mean Reading Class Achievement Grades according to gender and their Reading Strategies Metacognitive Awareness scores ( $\mathrm{p}=0.086)$. There is no statistically significant difference between the mean values of Global Reading Strategies Score ( $\mathrm{p}=0.756)$, Problem Solving Strategies score mean values ( $\mathrm{p}=0.883)$, Mean values of Support Reading Strategies Score ( $\mathrm{p}=0.579)$ and Reading Strategies Metacognitive Awareness scale mean scores $(\mathrm{p}=0.701)$ according to gender. According to this result, it is revealed that the strategy levels exercised by female and male students are close to each other and that they do not have superiority over each other in terms of level.

The findings regarding the 3rd question, "Is there a significant difference between students' reading strategies metacognitive awareness levels and their success grades in the reading course?", of the research are indicated in Table 6. 
Table 6. Examination of the Relationship Between Reading Course Success Grade and Reading Strategies Metacognitive Awareness Scale Scores

\begin{tabular}{lcc}
\hline & Reading Lesson & Success Score \\
\cline { 2 - 3 } & $\mathrm{r}$ & $\mathrm{p}$ \\
\hline Global Reading Strategies & 0,286 & 0,113 \\
Problem Solving Strategies & 0,097 & 0,598 \\
Support Reading Strategies & 0,165 & 0,366 \\
Reading Strategies Metacognitive Awareness Scale Overall Score & 0,236 & 0,193 \\
\hline
\end{tabular}

r: Pearson correlation coefficient

According to this result, when Table 6 is reviewed, it is observed that there is no statistically significant relationship between the Reading Class Success Score and Global Reading Strategies, Problem Solving Strategies, Reading Supporting Strategies scores and scale general score ( $\mathrm{p}>0.050)$.

\section{Conclusion and Recommendations}

In this study, reading strategies metacognitive awareness levels of the $1^{\text {st }}$ grade students studying at Anadolu University Faculty of Education Program of French Language Teaching have been examined in terms of gender and reading course success grade variables. The importance of reading and understanding in a foreign language is emphasized through many research conducted in the field. In this context, it is of utmost importance to determine what language learners do mentally during the reading process, what solutions they produce when they encounter a problem, and what methods they use to facilitate their understanding. These entire processes are performed through the use of metacognitive reading strategies.

In order to determine the metacognitive awareness levels of reading strategies of the $1^{\text {st }}$ grade students learning French language as a foreign language, the Turkish version of MARSI developed by Mokhtari \& Reichard (2002), adapted to Turkish by Mr. Öztürk (2012) has been applied. Considering the scores given by the students to the scale items and according to the evaluation scale given by Mokhtari \& Reichard (2002), in response to the first question of the research, which is "What is the level of metacognitive awareness of reading strategies of French foreign language students?" it has been determined that the students apply Global Reading Strategies $(3,75)$, Problem Solving Strategies (3.87) and Reading Support Strategies (3.51) at a high level.

In response to the $2^{\text {nd }}$ question (Is there a significant gender difference between students' reading success grades and reading strategies metacognitive awareness levels?) of the research, it is revealed that students' reading lesson success grades and reading strategies metacognitive awareness levels do not yield a significant difference in terms of gender. In similar studies, (Duran, 2011; Özsoy, Çakıroğlu\&Kuruyer, 2010; Özsoy\&Günindi, 2011; Erdem, 2012; Özdemir, 2018, cited by Azizoğlu\&Okur, 2020: 264) research is available revealing that the level of metacognitive awareness and the use of reading strategies do not differ based on the gender.

Moreover, no significant relationship was available between the findings of the $3^{\text {rd }}$ question (Is there a significant difference between students' reading strategies metacognitive awareness levels and their success grades in the reading course?) of the study. According to Anadolu University grading scale, a grade point average of 68.03 is accepted as a medium level grade point average. However, in the light of the data obtained, the high level of application of the entire strategies by the students cannot be associated with the success grade of the reading course. In this case, it has been observed that there was no great difference between the metacognitive awareness of reading strategies of male and female students whose reading course mean values were similar. In other words, it is revealed that the $1^{\text {st }}$ grade students are aware of these strategies and apply them at a high level, but despite this, they demonstrate a moderate level of success in the reading lesson. In this case, it can be considered that within the scope of French language reading course, students do not act very consciously with respect to the metacognitive reading strategies in classes and exams. The reason for this can be considered as the fact that they have problems in the application of the strategy especially in exams due to time and other concerns, and that they are insufficient in applying what they know.

As a result, in line with the findings of this study, it can be mentioned that although students' awareness of metacognitive reading strategies is high, they achieve a moderate level of success in applying them when their reading course success grade averages are considered. Moreover, it has been observed that no great difference is 
available between the strategy awareness levels of female and male students.

In conclusion, based on the findings of this study, the following recommendations can be presented. Thus, in foreign language courses, students can be made aware of the use of strategies by conducting a number of activities aimed at reading strategies. In this way, an increase in reading and understanding levels and academic achievement can be achieved by demonstrating the situation and how students should use strategies through activities. By emphasizing the importance of strategy use in terms of reading comprehension, students can be focused on the application of strategy.

In addition to the above suggestions, it can be ensured that students raise the awareness of the strategies they apply unintentionally by determining the strategies they apply whether intentionally or unintentionally, by performing situation determinations regarding the ways they follow while reading.

It is required to be demonstrated that using different types of texts (literary texts, proving texts, explanatory texts, informational texts, etc.) in reading courses, the application of strategies can also differ according to the type of text. At the same time, students' work on different types of text shall raise their interest in the course.

It can be observed whether or not the application of strategies vary based on the grade level by comparing the reading strategies metacognitive awareness of the students of French department on different grade levels $\left(1^{\text {st }}, 2^{\text {nd }}, 3^{\text {rd }}\right.$ and $4^{\text {th }}$ grade). Reading strategies of French students can be examined in terms of metacognitive awareness levels, other variables (age, number of foreign languages spoken, number of books read on a montly basis, etc.).

\section{References}

Akkaya, N. (2011). Effects of Using The Reading Comprehension Strategies on The Attitudes at Elementary School 8th Grade Turkish Course. Milli Eğitim, 191, 68-77. https://dergipark.org.tr/tr/download/article-file/442531

Aktaş, N., \& Ertem, İ. S. (2016). The Effect of Pre-Reading Strategy on Screen Reading Comprehension. Akademik Sosyal Araştırmalar Dergisi, 4(36), 131-157.

Anderson, N. J. (2002). The Role of Metacognition in Second Language Teaching and Learning. ERIC Clearinghouse on Languages and Linguistics, 1-7.

Auerbach, E. R., \& Paxton, D. (1997). "It's not the English Thing": Bringing Reading Research into the ESL Classroom, TESOL Quarterly, 31(2), 237-261. https://doi.org/10.2307/3588046

Ay, S. (2008). Reading Strategies in Foreign Language: A Case Study on Learners Who Are Smart in Different Ways. Dil Dergisi, 141, 7-18. https://doi.org/10.1501/Dilder_0000000095

Azizoğlu, N. İ., \& Okur, A. (2020). The Relationship Between Metacognitive Awareness Of Reading Strategies and Demographic Variables, Circadian Rhythm Characteristics Among University Students. Ana Dili Eğitimi Dergisi, 8(2), 258-269.

Başaran, M. (2013). 4Th Grade Students' Using Metacognitive Reading Strategies Conditions and Between The Relationship Reading Comprehension and Using These Strategies. Turkish Studies- International Periodical for The Languages, Literature and History of Turkish or Turkic, 8(8), 225-240. http://dx.doi.org/10.7827/TurkishStudies.5502

Bedir, S. B., \& Dursun, F. (2020). Students' Views on Metacognitive Reading Strategies Instruction. İnönü Üniversitesi Ĕ̆itim Fakültesi Dergisi, 21(1), 304-316. https://doi.org/10.17679/inuefd.533500

Carrell, P. L. (1989). Metacognitive Awareness and Second Language Reading. The Modern Language Journal, 72 , 121-134. Retrieved from https://www.jstor.org/stable/326568

Çetinkaya, G. (2004). Anadilinde ve Yabancı Dilde Okuma Sürecine Yönelik Gözlemler: Okuma-Anlama Stratejileri Üzerine Uygulamalı Bir Çalışma. Master's Thesis. Ankara Üniversitesi, Ankara.

Cornaire, C. (1999). Le Point Sur La Lecture. Paris: Clé International.

Dimmitt, C., \& McCormick, C. B. (2012). Metacognition in education. In K. R. Harris, S. Graham, and T. Urdan (Eds.), APA Educational Psychology Handbook, 1, 157-187, Theories, Constructs, And Critical Issues. Washington, DC: American Psychological Association. https://doi.org/10.1037/13273-007

Erdoğan, T., \& Yurdabakan, İ. (2018). Adaptation of Metacognitive Awareness of Reading Strategies Inventory: Turkish Higher Education Sample. Turkish Studies, 13(19), 669-680. http://dx.doi.org/10.7827/TurkishStudies.13814 
Ficher, R. (1998). Thinking About Thinking: Developing Metacognition in Children. Early Child Development and Care, 141, 1-15. https://doi.org/10.1080/0300443981410101

Grade Sheet of the Anadolu University. (2021). Retrieved from https://www.anadolu.edu.tr/ogrenci-isleri/orgun-bilgi-ve-belgeler/senato-ve-yonetim-kurulu-kararlari/not-karsili klari-ve-yabanci-dil-sinavlari-esdegerlikleri

Gül, S. (2020). An Investigation of Turkish as a Foreign Language Learners' Perceptions of Metacognitive Reading Strategies. Ph.D Thesis. Hacettepe Üniversitesi, Ankara.

Haukas, A. (2018). Metacognition in Language Learning and Teaching: An Overview. In Haukas, A., Bjorke, C., \& Dyphedahl, M. (Eds.), Metacognition in Language Learning and Teaching. New York: Routledge Studies in Applied Linguistics. Retrieved from https://library.oapen.org/bitstream/handle/20.500.12657/24185/1005946.pdf?sequence=1

Karasar, N. (1995). Bilimsel Araştırma Yöntemi. Ankara: 3A Araştırma Eğitim Danışmanlık.

Kuruyer, H. G., \& Özsoy, G. (2016). Investigation of Metacognitive Reading Skills of Good and Poor Readers: A Case Study. Kastamonu Ĕ̈itim Dergisi, 24(2), 771-788.

Mokhtari, K., \& Reichard, C. A. (2002). Assessing Students' Metacognitive Awareness of Reading Strategies. Journal of Educational Psychology, 94(2), 249-259. https://doi.org/10.1037/0022-0663.94.2.249

Öztürk, E. (2012). The Validity and Reliability of the Turkish Version of the Metacognitive Awareness of Reading Strategies Inventory. Elementary Education Online, 11(2), 292-305.

Pinninti, L. R. (2016). Metacognitive Awareness of Reading Strategies: An Indian Context. The Reading Matrix: An International Online Journal, 16(1), 179-193.

Pressley, M., \& Gaskins, I. W. (2006). Metacognitively Competent Reading Comprehension Is Constructively Responsive Reading: How Can Such Reading Be Developed in Students? Metacognition and Learning, 1, 99-113. https://doi.org/10.1007/s11409-006-7263-7

Rahimi, M., \& Katal, M. (2012). Metacognitive Strategies Awareness and Success in Learning English as a Foreign Language: An Overview. Procedia- Social and Behavioral Sciences, 31, 73-81. https://doi.org/10.1016/j.sbspro.2011.12.019

Randi, J., Grigorenko, E. L., \& Sternberg, R. J. (2008). Revisiting Definition of Reading Comprehension: Just What is Reading Comprehension Away. In S. E. Israel, C. C. Block, K. L. Bauserman \& K. Kinnucan-Welsch (Eds.), Metacognition in Literacy Learning. Matwah, NJ: Lawrence Erlbaum Associates. https://doi.org/10.4324/9781410613301

Reid, G. (2007). Motivating Learners in The Classroom: Ideas and Strategies. UK: Paul Chapman Publishing.

Rui, B. (2000). Exploration de la Notion de Stratégie de Lecture en Français Langues Étrangère et Maternelle. Acquisition et interaction en langue étrangère, 13, 1-17. https://doi.org/10.4000/aile.387

Şahan, A. (2012) Cognitive Reading Comprehension Strategies Employed By ELT Students. Sosyal Bilimler Enstitüsü Dergisi Sayl, 33(2), 1-22.

Stephanou, M., \& Mpiontini, M. H. (2017). Metacognitive Knowledge and Metacognitive Regulation in Self-Regulatory Learning Style, and in Its Effects on Performance Expectation and Subsequent Performance across Diverse School Subjects. Psychology, 8, 1941-1975. https://doi.org/10.4236/psych.2017.812125

Sucu, H. Ö. (2009). Contributions of Metacognitive Learning Strategies to The Development of Reading Comprehension in Foreign Language Teaching and Metacognitive Strategy Instruction (Nevsehir University sample). Master's Thesis. Erciyes Üniversitesi, Kayseri.

Temizkan, M. (2008). The Effects of Cognitive Reading Strategies on The Reading Comprehension Expository Texts in The Turkish Lessons. Gazi Eğitim Fakültesi Dergisi, 28(2), 129-148.

Teng, M. F. (2019). The benefits of Metacognitive Reading Strategy Awareness Instruction for Young Learners of English as a Second Language. Literacy, 00, 1-11. https://doi.org/10.1111/lit.12181

Vianty, M. (2007). The Comparison of Students' Use of Metacognitive Reading Strategies between Reading in Bahasa Indonesia and in English. International Education Journal, 8(2), 449-460.

Wang, M. T. (2009). Effects of Metacognitive Reading Strategy Instruction On EFL High School Students' Reading 
Comprehension, Reading Strategies Awareness and Reading Motivation (Ph.D Thesis). University of Florida, Florida. Retrieved from https:/ufdc.ufl.edu/UFE0041084/00001

Zhang, Z. (1993). Literature Review on Reading Strategy Research. A Paper Presented at the Annual Meeting of the Mid-South Educational Research Association. Educational Research Association. New Orleans, LA. ERIC, ED 366908. Retrieved from https://files.eric.ed.gov/fulltext/ED366908.pdf

\section{Copyrights}

Copyright for this article is retained by the author(s), with first publication rights granted to the journal.

This is an open-access article distributed under the terms and conditions of the Creative Commons Attribution license (http://creativecommons.org/licenses/by/4.0/). 